\title{
When Extremes Converge
}

German and Canadian Labor Migration Policy Compared

Holger Kolb

\author{
CMS 2 (1):57-75
}

DOI: 10.5117/CMS2014.1.KOLB

\begin{abstract}
Not only but particularly in terms of labor migration policy Germany and Canada are widely perceived as being situated at opposite ends of the spectrum. Whereas Canada has for a long time been enjoying a reputation of being one or even the role model for countries seeking to develop a flexible and welcoming immigration scheme that is nonetheless responsive to shortages and demands of specific sectors of the national labor market, the German system has been suffering from the suspicion of being not only structurally hostile towards immigrants but also of featuring a structural one-sidedness in terms of its steering, control and recruitment instruments. Against the background of major immigration reforms in the segment of highly skilled labor migration in both countries the paper describes and analyzes the core elements of these recent policy reforms, arguing that Canada and Germany as of 2013 increasingly display more similarities than differences in their high-skilled labor immigration policy. Both countries have departed from extreme and one-sided steering approaches and now run 'hybrid systems' that aim at making use of the advantages of different steering and recruitment approaches.
\end{abstract}

Keywords: Immigration Policy, Canada, Germany, Point Systems

\section{Introduction: Labor migration policy in Canada and Germany: Opposite ends of the spectrum?}

Canada and Germany constitute - at least as far as public perception is concerned - the most differing cases in terms of labor migration policies, 
in particular with regard to national schemes to attract highly skilled migrants. The Canadian approach, which first and foremost is based on a point system, is widely appreciated as a flexible, welcoming and efficient tool to attract highly qualified migrants from across the world. Jacoby (2010, p. 3) describes the Canadian point system as having "become a lodestar in international discussions of immigration - a model and an inspiration for policymakers around the world seeking to recruit high-skilled migrants for the sake of national competitiveness." The popularity of Canada as an efficient labor recruiting country has also spread in Europe. Academics and policy-makers in Germany are among those who joined the camp of the fans of Canada some years ago. In its first and final report ${ }^{1}$ the official statefunded Sachverständigenrat für Zuwanderung und Integration (Expert Council on Migration and Integration) (2004, p. 171, my translation) emphasized that countries that established immigration point systems in the past (particularly Canada, but also Australia and New Zealand) act politically reasonably and clear-sightedly, because the "straightforwardness and at the same time high functionality, the comparatively modest bureaucratic costs and [...] the flexibility, which makes this instrument particularly responsive to recent changes on the labor market" would explain to a large extent why countries with such systems outperform other countries with regard to the average level of migrant skills. Shachar (2006, p. 129) even goes as far as arguing that the "Canadian point system [...] represents an almost ideal example of how a smaller-economy jurisdiction can use immigration policy to establish a significant share of the overall worldwide intake of highly skilled migrants, even when it must directly compete with a neighboring economic giant like the United States." In German parliamentary debates about labor migration and shortage of workers it has meanwhile become commonplace to refer to Canada and the Canadian point system with praise and admiration. ${ }^{2}$

Germany on the other hand is at least in the public perception the opposite of Canada and has unfortunately become quite infamous for being a notoriously passive, narrow-minded and restrictive country in terms of labor migration in general and of its attempts to become an attractive destination country for skilled and highly skilled migrants (from non-EU countries) in particular. In an international survey among business executives, conducted 2012 on behalf of the World Competitiveness Yearbook, German respondents - in comparison to executives in most other OECD countries - very often expressed that the German "immigration laws prevent their company from employing foreign labour” (OECD, 2013, p. 120) because of their restrictiveness and inflexibility. In a statement for 
the Committee on Internal Affairs of the German Bundestag, one of the most prominent legal scholars in the field of migration and asylum law, Daniel Thym (2012, p. 3, my translation), reports that despite the recent comprehensive and liberal reforms "even on international scientific conferences $[. .$.$] many colleagues act on the assumption that Germany regulates$ economic migration restrictively".

The above depicted diverging images of the German and Canadian skilled labor migration regime build the foundation for contrasting the public and political perception of both countries concerning the general political approach towards labor migration with the respective policies in place to attract highly skilled migrants. The following considerations thus largely ignore the respective political discourses and instead focus on the description and comparative analysis of a specific segment of labor migration policy. The analysis also needs to block out many other aspects of immigration and integration policies such as naturalization, asylum and refugee policy, anti-discrimination policy, family reunion or integration measures. ${ }^{3}$ In this paper, the sole common reference point when comparing Canada and Germany is the development of the respective approaches of screening and selecting highly skilled migrants who in the case of Canada can immigrate and settle right from the start or in the case of Germany are first granted access on a temporary basis with the possibility to get a permanent residence after a certain period of time. Given the very recent changes in both countries it is furthermore not possible to say much about the desired effects of the respective new measures. This applies even more as volume and composition of immigration also depend on the supply side. For the German case it is also necessary to clarify that citizens of member states of the European Union are not subject to any German immigration legislation since they enjoy freedom of movement and have a (nearly) unlimited right to migrate to and live in any EU member state.

After briefly introducing a typology of recruitment schemes in Part 2, which is thought to be needed as an analytical template, Part 3 provides a brief review of the main elements of each country's system of highly skilled labor recruitment and indicates the different starting points and initial trajectories of both countries. Based on this, Part 4 highlights recent policy developments in Germany and Canada and provides the necessary empirical material to support the hypothesis of a convergence process in the policy dimension. Finally, in Part 5 some preliminary considerations about the potential drivers and dynamics of this convergence process are introduced. 


\section{Employer-based programs, occupation-driven schemes, human capital-approaches: A typology of labor migration schemes}

In order to support the hypothesis that the Canadian and the German labor immigration policy systems, which have for a long time been perceived as very different in structure and often even as structurally too different for any approximation, are now converging towards a hybrid system, it is necessary to analyze both cases under the same analytical framework. While the past years have seen an increase in public approaches to attract highly skilled migrants, various scholars have been striving to develop a systematic and relatively general framework to categorize and compare these migrant recruitment schemes. The most widespread approach to classify different state approaches to recruit labor migrants is to distinguish between demand- and supply-driven systems: whereas the central feature of the first approach is that "the initiative for the migration comes from the employer, who has a perceived need for a worker with a particular skill", the second approach refers "to situations in which a host country advertises its willingness to take applications for immigration directly from potential candidates, independently of a specific job offer" [...]; "candidates [in such systems] are usually assessed for admission on the basis of characteristics deemed to facilitate labor market integration such as language proficiency, educational attainment, age, work experience, the presence of family in the host country [...]" (Chaloff \& Lemaittre, 2009, p. 17). ${ }^{4}$ Another and for the purpose of this paper heuristically more useful differentiation comes from Papademetriou \& O'Neill (2004, p. 9) who propose a more fine-grained approach identifying three ways to screen and select labor migrants:

1. Employment-based systems admit "workers who have been hired by duly registered corporate entities for a specific job" and make admission first and foremost dependent on the question whether an applicant has found an employer and signed a work contract ${ }^{5}$,

2. Occupation-driven mechanisms admit "people who are qualified in occupations that the government decides are in short supply", capitalizing on the identification of labor shortages in specific occupations and/or sectors of the national economy and establishing 'fast track schemes' with eased access for persons with qualifications in these occupations and/or sectors without necessarily requiring a work contract.

3. Fundamentally different from these approaches are human capital schemes that usually not only refrain from any built-in requirement of arranged employment but are also not restricted to specific occupa- 
tions and/or sectors of the economy. This philosophy of screening and selecting applicants is rather based on an assessment of the observable characteristics of any individual applicant. A very popular method to do this assessment is the allocation of points.

\section{Employer-based vs. human capital-driven: German and Canadian strategies of labor recruitment}

The above-mentioned typology of labor migration schemes easily shows that for a long time Germany and Canada have indeed followed fundamentally different tracks with regard to labor immigration policy in general and to the recruitment of highly skilled migrants in particular. A very brief comparison of the institutional backbones, that have been forming the labor migration systems in both countries, indicates that the differences between the very principles of labor recruitment were not of gradual but of categorical nature.

Germany has a long experience of recruiting labor migrants. Between 1955 and 1973 more than four million immigrants, who were recruited under the assumption that their stay in Germany would be of temporary nature and thus politically and publically were addressed as "guest workers", came to Germany (Triadafilopoulos \& Schönwälder, 2006, p. 1-19). This immigration and the subsequent processes of family reunification are still influential for patterns of immigration to contemporary Germany. The German recruitment efforts seemed to be inevitable at that time in view of a significant labor supply problem which itself emerged out of a bundle of reasons: increasing demand as a consequence of economic growth, the reduction of labor supply induced by the establishment of armed forces, the building of the Berlin wall, the expansion of secondary and higher education which delayed the labor market participation of younger persons and finally successful efforts of trade unions to reduce the number of hours worked per week which had the same detrimental effect on labor supply. After nearly two decades of active labor migration policy Germany closed the door to 'third country' immigration in 1973, categorically refused to be a 'country of immigration' and only started to carefully change its stance towards labor immigration at the end of the 199os.

In Germany the attraction of highly skilled migrants from outside the European Union was traditionally either based on the provisions of the ordinance on exemptions from the recruitment ban (Anwerbestoppaus- 
nahmeverordnung - ASAV) or on the employment ordinance (Beschäftigungsverordnung - BeschV) respectively, which replaced the ASAV after the enactment of the immigration law of 2005. These ordinances served as a kind of exception list for circumstances under which the recruitment ban of 1973, which bars the recruitment of labor migrants from outside the European Union, could be abrogated (Schönwälder, 2013). For most of these exceptional cases, however, the respective conditions were formulated in a very strict way with a high level of discretionary power for the immigration bureaucracy with the result that Germany experienced a quasi-zero labor migration until the late 1990s. The German Green Card of 2000, a special arrangement for third country nationals with professional expertise in the field of information and communication technology ${ }^{6}$, and the immigration act of 2005 did also not fundamentally change the very nature of the German system (OECD, 2013, p. 64). Both schemes, the Green Card and the immigration act, only provided an increasing list of exceptions to the rule and cautiously liberalized the conditions for recruitment and labor immigration instead of changing the underlying rationale and rules. The common feature of ASAV, the Green Card and the options codified in the immigration act was the centrality of the requirement of a work contract (SVR, 2011, p. 71), which turned the German system into a model for an employer-based recruitment model, even though some provisions of the BeschV additionally required an affiliation to a specific sector of the economy or a particular educational degree, thereby including sector-specific or occupation-driven aspects.

The history of Canadian labor immigration policy could not be more different. Its self-understanding as a country of immigration which for many reasons is in need of and welcomes permanent immigration belongs to the country's political and societal DNA (Reitz, 2013, p. 154). This positive stance towards permanent immigration, moreover, seems to be disconnected from the business cycle and also holds for times of economic problems or even hardship. Even during the recent economic downturn no serious and/or influential political and societal voices arguing for reduced immigration emerged. The immigration outlook series of the OECD constantly ranks Canada as one of the top receivers of permanent immigration relative to its population.

Given the differences in the political and historical appreciation of immigration policy it cannot be surprising that the technical implementation of labor migration policy in Canada followed an entirely different approach than in Germany. In the same way as German labor migration policy has long been fixed exclusively on employer-based considerations, the Canadian philosophy of screening and selecting immigrants - particularly as 
institutionalized in the Federal Skilled Worker Program (FSWP) - reflected the human capital approach. Even though the FSWP is not the only labor migration scheme to Canada ${ }^{7}$, it is a very or even the most important one. Especially after the major reform of 2002 (Immigration and Refugee Protection Act - IRPA) this scheme solely relied on the human capital approach (Langenfeld \& Waibel, 2013 and O'Shea, 2009). Whereas Germany used the existence of a work contract that secured and guaranteed successful labor market integration as the central necessary (but not sufficient) condition for granting access, Canada pursued a strategy that only checked the characteristics of the individual applicant and barely took into account the specific needs of the domestic labor market. It relied on the assumption that in the long run highly qualified immigrants will find their way into the different realms of society, including the labor market, anyway (Hailbronner \& Koslowski, 2008, p. 7).

\section{The triumph of hybrid models and a process of convergence in Canada and Germany}

Recently both the German and Canadian government introduced major reforms of their migration policy instruments, reflecting a change in the general strategy on how best to attract high skilled migrant workers. These reforms significantly changed the traditional principles in both countries but remain barely known on the respective other side of the Atlantic so far. Whereas in German media and politics the Canadian point system of 1967 is still being praised for - among other things - its openness and flexibility ${ }^{8}$ ministerial instructions in 2008 tentatively removed the 'human capital core' of the system (which is defined above as exclusive consideration of individual characteristics such as education, age, work experience etc.) and severely restricted access to the system by installing and preceding two 'entry conditions': in order to be considered as applicant to the point system at all, potential immigrants must now prove a job offer or job experience in a specific, state-defined shortage occupation. ${ }^{9}$ Belonging to a specific occupational group is not a completely new feature in the Federal Skilled Worker Program (FSWP). Before the Immigration and Refugee Protection Act (IRPA) had removed occupational points entirely from the system, occupation was just one selection criterion among others. The ministerial instructions of 2008 turned occupation into "a preliminary screen", stipulating that only after "applications [have] pass[ed] through the "gate" established by the ministerial instructions they continue to be assessed 
against the IRPA human capital factors" (O'Shea, 2009, p. 22). This means that unless applicants "have Canadian job offers in hand, new applicants who do not qualify for the posted list of occupations in demand are not eligible for processing; their files are returned and their application fees refunded" (Picot \& Sweetman, 2012, p. 20).

These conditions also constitute the essence of the new FSWP that came into effect in spring 2013: just in order to get to the assessment stage candidates must pass one of three possible 'gates': 1) having a record of one year's work in one of the (now) 24 designated occupations; 2) having a qualifying offer of employment; 3 ) being eligible through the $\mathrm{PhD}$ stream for international students or graduates who are or were enrolled in a PhD program of a Canadian university. After having passed through this filter candidates are still assessed according to a revised points system. In addition to this, a minimum language requirement (Canadian Language Benchmark (CLB) 7) was introduced which categorically excludes applicants without sufficient language proficiency in English or French. In the older versions of FSWP the disadvantage of limited language proficiency could have been compensated by a high scoring among the other selection factors.

For 2015 the Canadian government plans the introduction of an "Expression of Interest (EoI)" selection system similar to the ones already implemented in Australia and New Zealand. Both countries constitute the main countries of reference with regards to the advancement of Canadian recruitment schemes. An EoI serves as a kind of preliminary stage for applicants and enables the public and private sector of a particular immigration country to identify at an earlier stage those candidates who are deemed to have the potential to pass the thresholds of the latter phases of the selection process. Particularly the possibility to involve employers early in the process indicates the new emphasis of labor market suitability and shrinking relevance of classic human capital-based considerations.

The trigger for this renunciation of the Canadian human capitaltradition on the one hand was a massive backlog of applications within the FSWP ${ }^{10}$ that was meant to be reduced by the introduction of these new entry conditions. On the other hand the unsatisfactory labor market integration of highly-skilled immigrants in Canada and a resulting Brain Waste (see O'Shea, 2009, Reitz, 2013; Picot \& Sweetman, 2012) may have been contributing to a further emphasis of the actual needs of the Canadian labor market in the system. As a matter of fact these ministerial instructions diversified the Canadian steering principles by adding employer-based and occupation-driven considerations to the formerly one-sided Canadian human capital system with the result "that the program as a whole is now 
more connected to labor market demand than was the case with the original IRPA scheme" (O'Shea 2009, p. 22). What is more, the way the individual level of education is taken account of in the point system has changed. The new system makes the assessment of foreign educational credentials mandatory, thereby requiring checking for the comparative value of the degree obtained abroad. Against this background it is no overstatement to describe the Canadian development in the last decade as a comprehensive one. After the IRPA reform, the ministerial instructions of 2008 meant nothing less than a certain renunciation of human capital principles and a conversion to a mix of employer-based (arranged employment) and occupation-driven (work experience in certain occupational categories) steering, which indeed continued to make use of the principle of allocating points on the basis of human capital considerations, but just as a secondary filter.

The recent German history of labor immigration policy is by no means less comprehensive in content than the Canadian one. Milestones during the last fifteen years were the Green Card program that is widely appreciated as an important icebreaker for the political debate, which had previously been stuck for many years (Ette, 2003, p. 34; Jurgens, 2010, p. 345-355; OECD, 2013, p. 64). The German Green Card paved the way for the successor of the aliens' act of 1991 - the immigration act of 2005 - that, despite receiving justifiable criticism on single issues, is widely accepted as the first systematic legal attempt to make Germany more attractive for an increasingly sought after global mobile elite. The last reform step in the area of labor migration so far was the implementation of the EU directive 2009/50/EC of 25 May 2009 on the conditions of entry and residence of third-country nationals for the purposes of highly skilled employment (so-called Blue Card). At least for the time being, the implementation of the directive can be interpreted as one further significant step in a long process of liberalization of the labor migration rules that had entered into force with Germany's immigration act in 2005. Conditions for obtaining the EU Blue Card are: a German, a recognized foreign or a comparable foreign higher education qualification, evidence of an annual minimum gross salary of currently EUR 46.800 or in the case of an EU Blue Card being awarded to scientists, mathematicians and engineers, doctors and IT specialists evidence of a minimum gross salary of $36.200 € .{ }^{11}$ The Blue Card is a temporary permit which can be converted into a permanent permit after 33 or (in case of German language skills) 21 months. What is worth noting in the way the German government implemented the directive is a generally "migrant friendly" (Thym, 2012, p. 6, my translation) and generous approach. This applies to the general abolishment of a labor market test for Blue Card holders, wage ceilings at 
the lowest edge of what the EU has defined as minimum requirements and unlimited labor market access for family members of Blue Card holders (Langenfeld \& Waibel, 2013). The implementation of the European Blue Card directive thus resulted in a new round of liberalization of the existing system of employer-based and occupation-driven labor migration. Yet, these changes remained within the limitations of that system, i.e. without changing its structural foundations.

Of greater relevance for comparing Canada and Germany and arguing for the existence of a process of structural convergence is an entirely new feature of the German immigration system. Even though not stipulated by the EU directive it nonetheless fundamentally changed the very nature of the formerly one-sided employer-based system (Strunden \& Schubert, 2012; Steller, 2013; Langenfeld \& Waibel, 2013): The new article 18c of the immigration act in its version of August 2012 introduced for the first time in the history of German immigration legislation a residence permit for job-searching. This is not only a departure from the 'No immigration without labor contract'-dogma, that in a nutshell has been the center of the German labor immigration philosophy for decades. It is also nothing less than the introduction of a very basic, frugal and binary (yes/no) point system with just two accession criteria: an academic qualification and adequate means of subsistence for the planned duration of the stay. ${ }^{12}$ Thus, Germany now runs a labor migration system that still puts a heavy emphasis on employer-based steering principles, which is fine-tuned by occupation-driven considerations as the reduced wage requirements for certain shortage occupations laid out by the German implementation of the Blue Card directive indicate. Article $18 \mathrm{c}$ of the immigration act, however, added a new legal option, that leaves the German tradition of labor migration policy behind and instead carefully employs the Canadian principle of a human capital model. It uses individual characteristics such as level of education and the existence of sufficient financial means for screening and selecting applicants. It is important to mention though that this new scheme remains closely linked to the so-far prevailing employer-based philosophy since access is only granted on a temporary basis (up to six months) until the migrant finds a job. He or she may then convert the temporary status into a permanent one.

A process of convergence on the modalities of recruitment schemes between Canada and Germany thus becomes apparent in the diversification of the respective steering principles and the emergence of hybrid models (Papademetriou \& Sumption, 2011) in both countries that tend to combine the screening and selecting mechanisms of different labor migration policy 
approaches. This is not the only development that indicates an increasing convergence between both countries. What furthermore deserves attention but is beyond the scope of this paper and cannot be explained in greater detail is the growing importance of the Canadian Temporary Foreign Worker Program (TFWP $)^{13}$ which in the same way as the EU Blue Card directive first provides only a temporary permit which at a later point of time can be converted into a permanent one. This paper, however, concentrates only on the steering principles for recruitment schemes of highly skilled migrants. Both countries in this regard abolished a one-sided strategy and today rather aim at a flexible combination of elements of all three basic strategies - human capital, employer-based and occupation-driven. In this regard Canada and Germany are coming from very different starting points, the 'pure' human capital-approach in one country and the similarly one-sided employer based-model in the other, but are now in a process of convergence and approximation.

Considerations about possible changes of migration policy do not imply full congruence between the countries discussed here as the mere respective quantitative dimension of labor or economic migration indicates: Whereas in Canada about two-thirds of the total immigration intake (about 249.0oo persons) come under the category of economic immigration (about 156.00o persons), for which the FSWP is just one (albeit the most important) element, labor migration to Germany constitutes a much smaller piece of the total immigration 'pie': In 2011 only 14 percent (about 37.00o) of all immigrants from third countries registered in the central register of foreigners (about 266.0oo), which statistically covers immigrants with a minimum period of stay of three months and thus does not include seasonal workers, came as labor migrants. The new entry gates for highly qualified non-EU citizens are not being used to a great extent so far (as also the monthly migration monitor of the Federal Office for Migration and Refugees indicates). The specific situation of Germany being the most important net receiver of immigrants from other EU member states, however, aggravates the quantitative comparison of both countries. Although it is statistically impossible to detect the actual underlying motives of EU immigrants to Germany it has a lot to commend that a significant share of the $500.000 \mathrm{EU}$ migrants in 2011 came to Germany as labor migrants (SVR, 2012, p. 49-66). The free movement of EU-citizens, who are largely well educated (SVR, 2012, p. 99-104), to Germany thus serves de facto as a functional equivalent and complementation to recruitment schemes for highly skilled immigrants.

Whereas the numbers of high-skilled immigrants remain unequal so far, which, however, not only can be explained by the fact that Germany only 
recently changed and opened its recruitment schemes (which apply to a rather small part of total migration to Germany), but also by the existence of a huge pool of mobile Europeans, which legally and statistically cannot be counted as 'immigrants' in the same way as third country nationals, the legal provisions in both countries show some tendencies of convergence. Canada diversified its formerly one-sided human capital model by utilizing instruments known and proven in employer-based systems. The German system, that traditionally featured a structural one-sidedness due to its categorical requirement of a work contract for all labor migrants, largely remains an employer-based system since the core of the German system, the temporary options of article 18 immigration act and the 'Blue Card options' of article 19 continue to be bound to a work contract. Yet the new article 18 c, which was not required to introduce by the EU Blue Card directive, added a second structural tier and thus resulted in an important diversification and hybridization of the German portfolio of labor market schemes.

\section{Causes of congruence and an emerging debate about rapid policy changes}

The market for highly skilled migrants is increasingly becoming an asymmetrical market in the sense that power is shifted from the now mutually competing immigration states (demanders) to a mobile and highly skilled workforce (suppliers), which aggravates analyses of the interrelation between policy changes and their desired effects and results in an institutional "race to the top" (Shachar, 2006). As far as the legal and institutional design of the approaches in Canada and Germany is concerned the differences are smaller than what could be assumed on the mere assessment of their respective reputation. In this process of convergence Germany undoubtedly went through greater changes than Canada, since in a rather short time it not only rigorously liberalized an existing employer-based labor migration scheme but also added an entirely new steering element based on human capital considerations to the overall set of measures to attract highly skilled migrants. This process resulted in a rather quick transformation of Germany from a country with a cautious and restrictive approach towards immigration policy as an instrument of labor market policy to a country that can be characterized by a new openness and generosity to labor migration. In a recent report on German labor immigration policy the OECD (2013, p. 15) came to a clear and unambiguous conclusion: "Recent reforms have put Germany among the OECD countries with the fewest restrictions on 
labour migration for highly skilled occupations", in fact "Germany's policy for highly skilled migration is among the most open in the OECD."

The assessment that something unexpected happened - and the claim that a process of convergence between Canada and Germany in the realm of migration policy is taking place undoubtedly belongs to this category - automatically raises the question of possible explanations. Particularly Germany's transformation from a "reluctant" (Martin, 1994, p. 189-225) and "undeclared" (Thränhardt, 1995, p. 19-35) country of immigration to a country which according to the recent assessment of the OECD nowadays - at least as far as recruitment schemes for highly skilled are concerned - belongs to the liberal pioneers, demands further explanation. The theoretical literature on policy change is rich (see for many others Hall, 1993 and Sabatier \& Jenkins-Smith, 1993). In a recent overview on theoretical explanatory offers for radical policy changes Rüb (2014, p. 13-15, my translation) differentiates between "external or internal shocks", "evolutionary learning" and "electorate-driven adjustment dynamics". Particularly the notion of "evolutionary learning" might serve as a fruitful starting point to dive into an explanation of why the development towards convergence took place, because this concept can easily be linked to the mentioned international trend towards the emergence of hybrid models of screening and selecting highly skilled migrants. The term "hybridization" generally describes a process of diversification of state portfolios of labor migration policy in such a way that systems that initially were based exclusively on employer-based considerations are now combined with human capital elements of screening and selecting (and vice versa). The policy-variation that has been described and analyzed as significant policy change for Germany (and to a lesser extent also for Canada) thus could be interpreted as part of a cross-country "tendency of policies to grow more alike, in the form of increasing similarity in structures, processes, and performances" (Drezner, 2001, p. 54). The common denominator of the here compared cases is an eclectic combination of different steering principles and selection instruments.

The reasons for an observed growing approximation of national policies and institutions are a central topic in various neoinstitutionalist studies. As a prominent and fruitful explanation within this stream of literature serves the concept of institutional isomorphism, which is described in general terms in the spadework of DiMaggio \& Powell (1983, p. 149) as a "constraining process that forces one unit in a population to resemble other units that face the same set of environmental conditions". The concept was originally developed for the analysis of processes within organiza- 
tions ("organizational fields"), but can nevertheless also be applied to the analysis of processes of political convergence (Holzinger \& Knill, 2007, p. 89). A 'competitive' version of isomorphism refers to adjustment processes triggered by market forces (see for such an account Shachar, 2013, p. 85-104). In contrast to this understanding "institutional isomorphism" analyses processes of adjustment and convergence beyond market-based reactions and competitive imperatives and puts a stronger emphasis on the significance of "political power and institutional legitimacy"(DiMaggio \& Powell, 1983, p. 150). Within the concept of institutional isomorphism three different mechanisms need to be differentiated. ${ }^{14}$ The form of isomorphism that contains specific importance for the case study of German and Canadian labor migration policy is mimetic isomorphism, understood as a specific strategy chosen by organizations and/or states in order to cope with insecurity or ignorance and to create legitimacy for political decisions by imitating political action of other states. Applying this analytical concept allows for avoiding mere functionalist explanations which tend to explain adjustment processes mainly or exclusively as a result of increasing international competition and a resulting similarity of societal conditions. Instead, political strategies for dealing with insecurity and creating legitimacy are used as the analytical focus.

For this case study of labor migration policy the notion of institutional isomorphism is assumed to have greater explanatory power than a reference to market dynamics and resulting adjustments because of the fact that the overall effectiveness of migration policies in general, including that of schemes to attract highly skilled immigrants, should not be exaggerated. A specific design of selective immigration policies seems to be only loosely coupled with the political outcomes defined for this policy area, which are the number and the human capital of labor migrants. Ambiguity and insecurity with regards to the interdependencies between legal migration rules and actual immigration outcomes prevail. The impact of state migration policy on immigration patterns tends to be overestimated, welldocumented self-selective processes of immigrants point to the importance of general socio-economic (see for example Cohen, Haberfeld \& Kogan, 2008, p. 185-201) and sociocultural conditions such as return on human capital, net wages, language and density of ethnic networks (see for example Boeri, Brücker, Docquier \& Rapoport, 2012) in the decision of where to migrate. As the outcome of specific policy options is hence vague, a policy of "modeling" and "mimetic behavior" turns out to be an attractive political option as "response to uncertainty" (DiMaggio \& Powell, 1983, p. 151). In this process of policy isomorphism the real effect of the policy measures is of secondary 
importance since the main goal of the measure is the reduction of political uncertainty. The basic point of reference of this "model copying" (Bommes, 2006, p. 70) for the case study analyzed here is the idea of hybrid systems of labor migration policy which have (seemingly) the potential to combine the specific (expected rather than proven) advantages of different steering approaches. In the face of the impossibility to describe the volume and composition of the immigration population solely as a result of a specific technique of screening and selecting and a corresponding chronic insecurity, imitating and following international trends, as Germany did by the adoption of a point system and Canada did by re-implementing arranged employment and the affiliation to a specific sector of the economy as a main category for selection and plans to do by adopting EoI-systems, appears to be a particularly attractive political reaction. The reference to institutional practices in other countries - this is referred to as the "ritual aspect" by DiMaggio \& Powell $(1983$, p. 151) - promises to maintain or even increase the legitimacy of political reforms. In Germany the necessary implementation of the Blue Card directive provided a politically convenient window of opportunity for model copying in the shape of a hybridization of labor migration policy. In this time frame the sudden renunciation of a fixation on a work contract as conditio sine qua non for immigrating seemed to be manageable. In Germany this change furthermore was easy to legitimize as a possible solution to the problem that Germany for a long time seemingly attracted mainly low qualified and therefore the 'wrong' kind of migrants.

Moreover, this discussion of German migration policy can be related to an emerging theoretical debate within political science in Germany. In two recent papers Rüb $(2012 ; 2014)$ pointed to an increasingly puzzling phenomenon to be observed in Germany that he calls "rapid policy changes". The most striking and publicly most debated examples for these changes took place in the realm of social and labor market policy (massive social cuts in welfare benefits, enacted by a center-left government), energy policy (abandoning nuclear energy, enacted by a center-right government) and defense policy (abolition of compulsory military service, enacted by a center-right government). These political U-turns are particularly startling in Germany because the country has for a long time been perceived "in international comparative as well as in German policy-research as a prototype of a political regime, in which policy changes are unlikely and which notoriously leads to a backlog of reforms" (Rüb, 2014, p. 3; my translation; see also the spadework on Germany by Katzenstein, 1987). These changes challenge political science to develop a new typology and taxonomy of rapid policy changes that have the analytical potential to explain the recent ac- 


\section{cumulation of unexpected changes. The current history of migration policy may fit very well into the list of policy fields that underwent such a change.}

\section{Acknowledgements}

I would like to thank two anonymous reviewers as well as Caroline Schultz and the participants of the workshop “Germany's immigration and integration experience - Lessons for Canada" for their valuable comments.

\section{Notes}

1. After original plans to introduce a point system already with the immigration act of 2005 were skipped and thus a key part of the mandate of the council, the setting of a maximum quota of labor migrants to be admitted, ceased to exist, the budgetary committee of the federal parliament withdrew all funds and thus de facto dissolved the council.

2. See for example the proposition 17/3862, discussed in the German Bundestag in November 2010 and the proposition 16/8492 from March 2008. See for an analysis of the German parliamentary debate on this topic Schönwälder (2013, p. 273-286).

3. In most of these areas the two countries remain rather different or processes of convergence are slow and unsteady. See e.g. Koopmans, Michalowski \& Waibel (2012, p. 1202-1245).

4. A similar theoretic distinction is made by a recent study of the Berlin-Institut (2012, p. 35-36) that differentiates between "human capital-oriented models" vs. "labor marketdriven methods" to emphasize the different philosophies of Germany and Canada in the past and by Papademetriou \& Sumption (2011, p. 2-3). Their differentiation of methods of "points-based selection" that are predicated on a "list of attributes or characteristics that [governments] deem important for prospective foreign workers to possess to be admitted" and "employer-led systems" that "rel[y] on employers to choose workers" largely corresponds to the distinction between supply- and demand-driven systems as proposed by Chaloff \& Lemaître (2009).

5. Arranged employment is thus a necessary but not a sufficient condition for access.

6. Originally the government planned to attract up to 20.000 IT specialists. Particularly the economic downturn of the IT industry shortly after the launch of the Green Card severely reduced the demand for foreign workers, so that finally only about 15.000 work permits were issued.

7. Other important elements of the Canadian system of labor migration are the Provincial Nominee Program (PNP) that allows the Canadian provinces to nominate persons for immigrating to the respective province, the Canadian Experience Class (CEC), which eases access for persons who have already lived in Canada before, and the Temporary Foreign Worker Program (TFWP).

8. See for a very benevolent analysis of the Canadian approach the study of the Berlin-Institut (2012).

9. The list of occupations contains mainly engineers and medical professionals.

10. According to the official evaluation of the Federal Skilled Worker Program (CIC, 2010, p. 3) some applicants had to wait up to six years for the final handling of their application 
with the consequence that "these processing times certainly make Canada a less attractive destination for potential immigrants" (O'Shea, 2009, p. 15).

11. Average starting salaries for young academics are reported to range between $30.000 €$ for architects or social pedagogues and more than $50.000 €$ for engineers. Given an average starting salary for all academics of $41.000 €$ the wage requirements of the Blue Card must be considered as moderate. It is further interesting to know that the initial annual minimum gross salary for obtaining a high-quality residence permit was above $80.000 €$ when the German immigration act for highly skilled immigrants first entered into effect in 2005.

12. If a person is able to meet these two criteria he/she is allowed to look for a job in Germany for up to six months. In case of being successful his/her permit will be renewed, extended and if applicable converted into a permanent permit. Translated into the point-system logic, this implies a maximum number of two points needed for admission.

13. In her comparison of Spain and Canada Finotelli (2012, p. 1-18) particularly highlights the increasing relevance of the TFWP as new feature in the Canadian immigration system. The number of temporary foreign workers in Canada increased from less than 50.000 in 1988 to more than 210.000 in 2012 and is almost as high as the number of permanent immigrants (Worswick, 2013, p. 5).

14. In contrast to mimetic isomorphism coercive isomorphism describes a process when an organization is compelled to adopt structures or rules (through laws, regulations or accreditation processes). Finally, normative isomorphism is associated with professional values.

\section{References}

Berlin-Institut für Bevölkerung und Entwicklung (2012). Nach Punkten vorn. Was Deutschland von der Zuwanderungs- und Integrationspolitik Kanadas lernen kann. Berlin.

Boeri T., Brücker H., Docquier F. \& Rapoport H. (2012). Brain Drain and Brain Gain. The Global Competition to Attract High-Skilled Migrants. Oxford: Oxford University Press.

Bommes M. (2006). Integration durch Sprache als politisches Konzept. In U. Davy \& A. Weber (Eds.), Paradigmenwechsel in Einwanderungsfragen? Überlegungen zum neuen Zuwanderungsgesetz (pp. 59-86). Baden-Baden: Nomos.

Chaloff J. \& Lemaître G. (2009). Managing Highly-Skilled Labour Migration: A Comparative Analysis of Migration Policies and Challenges in OECD Countries. Paris: OECD Social, Employment and Migration Working Papers No. 79.

Citizenship and Immigration Canada (2010). Evaluation of the Federal Skilled Worker Program. Ottawa.

Cohen, Y., Haberfeld, Y. \& Kogan, I. (2008). Jüdische Migranten aus der ehemaligen Sowjetunion. Ein natürliches Experiment zur Migrationsentscheidung. In F. Kalter (Ed.), Migration und Integration (Sonderheft der Kölner Zeitschrift für Soziologie und Sozialpsychologie) (pp. 185-201). Wiesbaden: VS Verlag.

DiMaggio, P.J. \& Powell W.W. (1983). The Iron Cage Revisited: Institutional Isomorphism and Collective Rationality in Organizational Fields. American Sociological Review, 48, 147-16o.

Drezner, D.W. (2001). Globalization and Policy Convergence. Journal of European Public Policy, $12,53-78$.

Ette, A. (2003). Germany's Immigration Policy, 2000-2002. Understanding Policy Change with a Politcal Process Approach. Bremen: Center on Migration, Citizenship and Development.

Finotelli, C. (2012). Change of Paradigms? A Comparison of Canadian and Spanish Labour Migration Models. Journal of Comparative Policy Analysis, 15, 1-18. 
Hailbronner, K. \& Koslowski, R. (2008). Models for Immigration Management Schemes: Comparison and Analysis of Existing Approaches and a Perspective for Future Reforms. Washington DC: Immigration Paper Series.

Hall, P.A. (1993). Policy Paradigms, Social Learning, and the State: The Case of Economic Policymaking in Britain. Comparative Politics, 25, 275-296.

Holzinger, K. \& Knill, C. (2007). Ursachen und Bedingungen internationaler Politikkonvergenz. Politische Vierteljahresschrift, 38, 85-106.

Jacoby T. (2010). Selecting For Integration - What Role For A Point System?. Washington DC: Policy Brief for the German Marshall Fund of the United States.

Jurgens J. (2010). The legacies of labor recruitment: The guest worker and green card programs in the Federal Republic of Germany. Policy and Society, 29, 345-355.

Katzenstein P. (1987). Policy and Politics in West Germany: The Growth of a Semisovereign State. Philadelphia: Temple University Press.

Koopmans R., Michalowski, I. \& Waibel S. (2012). Citizenship Rights for Immigrants in Western Europe. American Journal for Sociology, 117, 1202-1245.

Langenfeld C. \& Waibel S. (2013). Von der Begrenzung zur Steuerung: Deutschlands Abkehr vom „widerstrebenden“ Einwanderungsland. In W. Fritzemeyer, G. Jochum \& M. Kau (Eds.), Grenzüberschreitendes Recht - Crossing Frontiers. Festschrift für Kay Hailbronner (pp. 169184). Heidelberg: C.F. Müller.

Martin P.L. (1994). Germany -Reluctant Land of Immigration. In W.A. Cornelius, P.L. Martin \& J.F. Hollifield (Eds.), Controlling Immigration: A Global Perspective (pp. 189-225). Stanford: Stanford University Press.

O'Shea E. (2009). Missing the Point(s). The declining fortunes of Canada's economic immigration program. Washington DC: Transatlantic Academy Paper Series.

OECD (2013). Recruiting Immigrant Workers: Germany. Paris.

Papademetriou D.G. \& O'Neill K. (2004). Efficient Practices for the Selection of Economic Migrants. Hamburg: HWWA Working Paper.

Papademetriou D.G. \& Sumption M. (2011). Rethinking Point Systems and Employer-Selected Immigration. Washington DC: Migration Policy Institute.

Picot G. \& Sweetman A. (2012). Making It in Canada: Immigration Outcomes and Policies. Montreal: IRPP Study.

Reitz J. (2013). Closing the Gaps Between Skilled Immigration and Canadian Labor Markets: Emerging Policy Issues and Priorities. In T. Triadafilopoulos (Ed.), Wanted and Welcome? Policies for Highly Skilled Immigrants in Comparative Perspective (pp. 147-163). New York: Springer.

Rüb F. (2012). Rapide Politikwechsel in der Demokratie: Gründe, Akteure, Dynamiken und Probleme. In J. Kersten \& G.F. Schuppert (Eds.), Politikwechsel als Governanceproblem (pp. 15-44). Baden-Baden: Nomos.

Rüb F. (2014). Rapide Politikwechsel in der Bundesrepublik: Mögliche Gründe, Akteure, Dynamiken und Probleme. Zeitschrift für Politik (forthcoming).

Sabatier P.A. \& Jenkins-Smith H.C. (1993). Policy Change and Learning: An Advocacy Coalition Approach. Boulder: Westview.

Sachverständigenrat für Zuwanderung und Integration (2004). Migration und IntegrationErfahrungen nutzen, Neues wagen. Berlin.

Schönwälder K. (2013). Germany: Reluctant Steps Towards a System of Selective Immigration. In T. Triadafilopoulos (Ed.), Wanted and Welcome? Policies for Highly Skilled Immigrants in Comparative Perspective (pp. 273-286). New York: Springer.

Shachar A. (2006). The Race for Talent: Highly Skilled Migrants and Competitive Immigration Regimes. New York University Law Review, 81, 148-206. 
Shachar A. (2013). Talent Matters: Immigration Policy Setting as a Competitive Cramble Among Jurisdictions. In T. Triadafilopoulos (Ed.), Wanted and Welcome? Policies for Highly Skilled Immigrants in Comparative Perspective (pp. 85-104). New York: Springer.

Steller B. (2013). Deutschland auf dem Weg zu einem Willkommensrecht? Zur Umsetzung der EU-Hochqualifiziertenrichtlinie in deutsches Recht zum 1.8.2012. Zeitschrift für Ausländerrecht und Ausländerpolitik, 33, 1-11.

Strunden M. \& Schubert M. (2012). Deutschland gibt sich „Blue Card Plus“ - EU-Richtlinie genutzt für Meilenstein der Arbeitsmigration. Zeitschrift für Ausländerrecht und Ausländerpolitik, 32, 270-275.

SVR (2011). Migrationsland 2011. Berlin.

SVR (2012). Erfolgsfall Europa? Folgen und Herausforderungen der EU-Freizügigkeit für Deutschland. Berlin.

Thränhardt D. (1995). Germany - An Undeclared Immigration Country. New Community, 21, 19-35. Thym D. (2012). Stellungnahme für die Öffentliche Anhörung des Innenausschusses des Deutschen Bundestags am Montag, den 23. April 2012 zum Gesetzentwurf der Bundesregierung zur Umsetzung der Hochqualifizierten-Richtlinie der Europäischen Union (BT-Drs. 17/8682 v. 15. 02. 2012). Berlin.

Triadafilopoulos, T. \& Schönwälder K. (2006). How the Federal Republic Became an Immigration Country. Norms, Politics and the Failure of West Germany's Guest Worker System. German Politics and Society, 24, 1-19.

Worswick, C. (2013). Economic Implications of Recent Changes to the Temporary Foreign Worker Program. Montreal: IRPP Insight.

\section{About the author}

Holger Kolb, Expert Council of German Foundations on Integration and Migration. Email:kolb@svr-migration.de

Holger Kolb is a senior researcher working for the office of the German Expert Council of German Foundations on Integration and Migration. His research interests are labor migration policy, migration theory and the politics of highly skilled migration.

\section{(1) (8)}

2014 Kolb / Amsterdam University Press.

This is an Open Access article distributed under the terms of the Creative Commons Attribution License (http:// creativecommons.org/licenses/by/2.o), which permits unrestricted use, distribution, and reproduction in any medium, provided the original work is properly cited. 